\title{
HUBUNGAN POLA MENSTRUASI DAN TINGKAT KONSUMSI ZAT BESI DENGAN KEJADIAN ANEMIA PADA REMAJA PUTRI
}

\author{
Association BetweenMenstrual Pattern and Level of Iron Consumtion with \\ Incidence of Anemia Among Adolescent Girls \\ Herlinadiyaningsih ${ }^{1}$, Rahel Pambuding Susilo ${ }^{2}$ \\ Poltekkes Kemenkes Palangka Raya \\ (herlinadiyaningsih@ rocketmail.com)
}

\begin{abstract}
ABSTRAK
Latar Belakang : Anemia merupakan permasalahan utama yang dialami oleh remaja, khususnya remaja putri di Asia Tenggara termasuk di Indonesia. Laporan berbagai studi di Indonesia memperlihatkan masih tingginya prevalensi kejadian anemia deisiensi zat besi pada remaja putri yang berkisaran antara 20-50\%.

Tujuan : Untuk mengetahui hubungan pola menstruasi (lama dan siklus menstruasi) dan tingkat konsumsi zat besi dengan kejadian anemia pada remaja putri di SMA Negeri 4 Palangka Raya.

Metode : Penelitian ini merupakan penelitian kuantitatif dengan rancangan cross sectional (potong lintang). Teknik pengambilan sampel yang digunakan adalah nonprobability sampling dengan jenis purposive sampling. Besar sampel yang digunakan sebanyak 147 remaja putri. Instrumen yang digunakan dalam penelitian ini adalah uji laboratorium secara point of care testing (POCT), kuesioner pola menstruasi, dan kuesioner Semiquantitative Food Frequency Questionnaire (FFQ).

Hasil : Dari 147 responden terdapat $66(44,9 \%)$ siswi yang mengalami anemia. Hasil uji statistik menunjukkan nilai p-value 0,000 ada hubungan antara kejadian anemia dengan lama menstruasi, siklus menstruasi dan tingkat konsumsi zat besi.

Simpulan : Ada hubungan antara pola menstruasi (lama dan siklus menstruasi) dan tingkat konsumsi zat besi dengan kejadian anemia pada remaja putri di SMA Negeri 4 Palangka Raya.
\end{abstract}

Kata Kunci : Kejadian Anemia, Pola Menstruasi, Konsumsi Zat Besi, Remaja Putri

\section{ABSTRACT}

Background : Anemia is a major problem experienced by adolescents, especially girls in Southeast Asia including in Indonesia. Reports of various studies in Indonesia show a high prevalence of iron deficiency anemia in adolescent girlsranging from 20-50\%.

The Purpose : To know the association between menstrual pattern (duration and menstrual cycle) and level of iron consumption with anemia incidence among adolescent girls SMA Negeri 4 Palangka Raya. 
Method :This research is quantitavie research with cross sectional design. The sampling technique used in this research is nonprobability sampling with purposive sampling type. The sample size is 147 girls. Instruments used in this study were laboratory test point of care testing (POCT), menstrual pattern queastionnaire, and questionnaire semiquantitavie food frequency questionnaire (FFQ).

Result :From 147 respondents there were 66 (44,9\%) of the schoolgirls who had anemia. The results of the statistic p-value 0,000, there is a relationship between the incidence of anemia with the duration of menstruation, the menstrual cycle and the level of iron consumption.

Conclusin : There is an association between menstual pattern (duration and menstrual cycle) and level of iron consumption with anemia incidence in adolescent girls SMA Negeri 4 Palangka Raya.

Key word : Anemia, Menstruasi Pattern, Iron Consumtion, Adolescent Girl

\section{PENDAHULUAN}

Berdasarkan hasil Sensus Penduduk tahun 2010, populasi remaja di Indonesia sebanyak 19,636 juta jiwa dan 46,6\% ialah remaja putri (BKKBN, 2012). Di kota Palangka Raya populasi remaja sebanyak 46.965 jiwa yaitu mencapai 18,07\% dari total populasi penduduk kota Palangka Raya (Profil Kesehatan Kalteng, 2015). Menurut WHO, banyak masalah pada remaja masih terabaikan disebabkan karena masih banyak faktor-faktor yang belum diketahui, padahal remaja merupakan sumber daya manusia Indonesia yang harus dilindungi karena potensinya yang sangat besar dalam upaya pembangunan kualitas bangsa (WHO, 2011).

Menurut Sustainable Development Goals (SDG'S), remaja putri merupakan calon ibu yang harus dipersiapkan untuk mengandung dan melahirkan dengan mengurangi resiko dalam kehamilan maupun saat melahirkan seperti anemia pada kehamilan serta perdarahan pasca persalinan. WHO menyebutkan bahwa permasalahan utama yang dialami oleh remaja, khususnya remaja putri di Asia Tenggara termasuk di Indonesia ialah anemia defisiensi zat besi (Fe) (WHO, 2011). Remaja putri lebih sering mengalami anemia dibandingkan dengan remaja putra disebabkan karena remaja putri mengalami menstruasi setiap bulannya. Peningkatan pengeluaran zat besi di karenakan adanya percepatan pertumbuhan lebih banyak asupan nutrisi khususnya zat besi (Istiyani, 2011).

Pola menstruasi pada remaja putri meliputi siklus menstruasi dan lama menstruasi. Siklusnya menstruasi adalah jarak antara mulainya menstruasi yang lalu dengan menstruasi berikutnya. Remaja putri yang mengalami siklus menstruasi pendek menyebabkan anemia (Wilyati, 2012). Lama menstruasi adalah waktu yang dialami seorang wanita selama proses menstruasi. Perbedaan lama menstruasi dipengaruhi oleh beberapa faktor yaitu faktor psikologis, lingkungan, usia, serta ketidakseimbangan hormon. Wanita dengan lama menstruasi yang 
terlalu lama menyebabkan darah yang keluar secara kumulatif lebih banyak sehingga kemungkinan terjadinya anemia (Fauziah, 2012).

Jumlah darah yang hilang selama satu periode menstruasi normal berkisar antara 20-25 cc dan dianggap tidak normal jika kehilangan darah saat menstruasi lebih dari $80 \mathrm{cc}$. Darah yang keluar dengan jumlah 20-25 cc menyiratkan bahwa kehilangan zat besi sebesar 0,5 mg setiap hari atau sebesar 12,5-15 mg setiap bulannya. Jumlah tersebut ditambah dengan kehilangan basal maka jumah total zat besi yang hilang sebesar 1,25 mg setiap harinya (Arisman, 2010). Seseorang dengan simpanan zat besi dalam jumlah normal akan mengabsorsi zat besi 5-10\% dari jumlah total masukan zat besi yaitu sekitar 0,5-2 mg setiap harinya. Banyaknya darah yang keluar berpengaruh pada kejadian anemia karena jika remaja putri tidak memiliki persediaan zat besi yang cukup dan absorpsi zat besi yang rendah dalam tubuhnya maka mekanisme tubuhnya tidak akan mampu menggantikan zat besi yang hilang selama menstruasi yang mengakibatkan remaja putri mengalami anemia (Soekirman, 2010).

Kekurangan zat besi dapat menimbulkan gangguan atau hambatan pada pertumbuhan sel tubuh maupun sel otak. Kekurangan kadar hemoglobin dapat menimbulkan gejala lesu, lelah, lemah, letih, sering pingsan dan cepat lupa. Akibatnya dapat menurunkan persentasi belajar, olahraga dan prodiktifitas kerja. Laporan berbagai studi di Indonesia juga memperlihatkan masih tingginya prevalensi kejadian anemia defisiensi zat besi pada remaja putri yang berkisar antara 20-50\%. Berdasarkan uraian di atas, maka peneliti tertarik untuk melakukan penelitian mengenai "Hubungan Pola Menstruasi dan Tingkat Konsumsi Zat Besi dengan Kejadian Anemia pada Remaja Putri di SMA Negeri 4 Palangka Raya".

\section{METODE PENELITIAN}

Penelitian ini merupakan penelitian analitik observasional dengan pendekatan cross sectional. Populasi penelitian adalah 652 siswi kelas X, XI dan XII yang bersekolah di SMA Negeri 4 Palangka Raya. Teknik pengambilan sampel yaitu purposive sampling. Sampel pada penelitian ini berjumlah 147 responden. Penelitian ini dilaksanakan di SMA Negeri 4 Palangka Raya pada bulan Februari-Maret 2018.

Pengumpulan data pada penelitian ini menggunakan uji laboratorium secara Point of Care Testing (PCOT), kuesioner pola menstruasi dan kuesioner Semiquantitative Food Frequency Questionnaire (FFQ) yang disebarkan pada responden dan melakukan pemeriksaan kadar Hemoglobin. 


\section{HASIL DAN PEMBAHASAN}

Tabel 1 Distribusi Frekuensi Karakteristik Remaja Berdasarkan Usia

\begin{tabular}{|c|c|c|}
\hline Karakteristik & Frekuensi(f) & $\begin{array}{c}\text { Presentase } \\
(\%)\end{array}$ \\
\hline $\begin{array}{l}\text { Usia } \\
14\end{array}$ & 2 & 1,4 \\
\hline 15 & 54 & 36,7 \\
\hline 16 & 64 & 43,5 \\
\hline 17 & 24 & 16,3 \\
\hline 18 & 3 & 2,0 \\
\hline Total & 147 & 100 \\
\hline
\end{tabular}

Berdasarkan tabel 1 diketahui remaja putri yang berusia 14 tahun berjumlah 2 responden (1,4\%), 15 tahun berjumlah 54 responden (36,7\%), 16 tahun berjumlah 64 responden $(43,5 \%), 17$ tahun berjumlah 24 responden $(16,3 \%), 18$ tahun berjumlah 3 responden $(2,0 \%)$.

Tabel 2 Distribusi Responden Menurut Lama Menstruasi, Siklus Menstruasi, Tingkat Konsumsi Zat Besi dan Kejadian Anemia

\begin{tabular}{ccc}
\hline Lama Menstruasi & Frekuensi (f) & $\begin{array}{c}\text { Persentase } \\
(\%)\end{array}$ \\
\hline Tidak Normal & 61 & 41,5 \\
Normal & 86 & 58,5 \\
Total & 147 & 100 \\
Siklus Menstruasi & & \\
Pendek & 69 & 46,9 \\
Normal & 54 & 36,7 \\
Panjang & 24 & 16,3 \\
Total & 147 & 100 \\
Tingkat Konsumsi & & \\
Zat Besi & 103 & 70,1 \\
Kurang & 44 & 29,9 \\
Cukup & 147 & 100 \\
Total & & 54,1 \\
Kejadian Anemia & 66 & 500 \\
Anemia & & \\
Tidak Anemia & &
\end{tabular}

Berdasarkan tabel 2 di atas menunjukkan lama menstruasi yang tidak normal berjumlah 61 responden $(41,5 \%)$ dan yang normal berjumlah 86 
responden $(58,5 \%)$. Siklus menstruasi yang pendek berjumlah 69 responden $(46,9 \%)$, siklus menstruasi yang normal berjumlah 54 responden $(36,7 \%)$ dan siklus menstruasi yang panjang berjumlah 24 responden $(16,3 \%)$. Tingkat konsumsi zat besi yang kurang berjumlah 103 responden $(70,1 \%)$ dan tingkat konsumsi zat besi yang cukup berjumlah 44 responden $(29,95 \%)$. Responden yang mengalami anemia berjumlah 66 responden $(44,9 \%)$ dan tidak mengalami anemia berjumlah 81 responden $(55,1 \%)$.

Tabel 3 Hubungan Lama Menstruasi dengan Kejadian Anemia Pada Remaja Putri

\begin{tabular}{|c|c|c|c|c|c|c|c|c|}
\hline \multirow{3}{*}{$\begin{array}{c}\text { Lama } \\
\text { Menstru } \\
\text { asi }\end{array}$} & \multicolumn{4}{|c|}{ Anemia } & \multirow{2}{*}{\multicolumn{2}{|c|}{ Total }} & \multirow{3}{*}{$\begin{array}{c}\text { OR } \\
(95 \% \mathrm{CI})\end{array}$} & \multirow{3}{*}{ P-Value } \\
\hline & \multicolumn{2}{|c|}{ Ya } & \multicolumn{2}{|c|}{ Tidak } & & & & \\
\hline & $\mathbf{n}$ & $\%$ & $\mathbf{n}$ & $\%$ & $\mathbf{N}$ & $\%$ & & \\
\hline $\begin{array}{l}\text { Tidak } \\
\text { Normal }\end{array}$ & 47 & 77,0 & 14 & 23,0 & 61 & 100 & & \\
\hline Normal & 19 & 22,1 & 67 & 77,9 & 86 & 100 & $\begin{array}{c}11,84(5,40- \\
25,95)\end{array}$ & 0,000 \\
\hline Total & 66 & & 81 & & 147 & & & \\
\hline
\end{tabular}

Berdasarkan tabel 3 diperoleh hubungan antara lama menstruasi dengan kejadian anemia, ada sebanyak $77,0 \%$ remaja putri dengan lama menstruasi yang tidak normal menderita anemia sedangkan remaja putri dengan lama menstruasi yang normal 22,1\% menderita anemia. Perbedaan ini bermakna secara statistik dengan $p$-value 0,000 , artinya ada hubungan yang signifikan antara lama menstruasi dengan kejadian anemia pada remaja putri dengan nilai $\mathrm{OR}=$ 11,84(95\% CI:5,40-25,95). Nilai tersebut menunjukkan bahwa remaja putri dengan lama menstruasi yang tidak normal 11,84 kali lebih beresiko untuk menderita anemia dibandingkan dengan remaja putri dengan lama menstruasi yang normal.

Tabel 4 Hubungan Siklus Menstruasi dengan Kejadian Anemia Pada Remaja Putri

\begin{tabular}{|c|c|c|c|c|c|c|c|c|}
\hline \multirow{3}{*}{$\begin{array}{c}\text { Lama } \\
\text { Menstruasi }\end{array}$} & \multicolumn{4}{|c|}{ Anemia } & \multicolumn{2}{|c|}{ Total } & \multirow{3}{*}{$\begin{array}{c}\text { OR } \\
(95 \% \mathrm{CI})\end{array}$} & \multirow{3}{*}{ P-Value } \\
\hline & \multicolumn{2}{|c|}{ Ya } & \multicolumn{2}{|c|}{ Tidak } & & & & \\
\hline & $\mathrm{n}$ & $\%$ & n & $\%$ & n & $\%$ & & \\
\hline Pendek & 45 & 65,2 & 24 & 34,8 & 69 & 100 & $\begin{array}{c}6,56(2,92- \\
14,76)\end{array}$ & 0,000 \\
\hline Normal & 12 & 22,2 & 42 & 77,8 & 54 & 100 & Pemb & ding \\
\hline Panjang & 9 & 37,5 & 15 & 62,5 & 24 & 100 & $\begin{array}{c}2,10(0,74- \\
5,98)\end{array}$ & \\
\hline Total & 66 & & 81 & & 147 & & & \\
\hline
\end{tabular}

Berdasarkan tabel 4 diperoleh hubungan antara siklus menstruasi dengan kejadian anemia bahwa sebanyak $65,2 \%$ remaja putri dengan siklus menstruasi 
yang pendek menderita anemia sedangkan remaja putri dengan siklus menstruasi yang normal $22,2 \%$ menderita anemia dan sebanyak $37,5 \%$ remaja putri dengan siklus menstruasi yang panjang menderita anemia. Perbedaan ini bermakna secara statistik dengan $p$-value 0,000 artinya ada hubungan yang signifikan antara siklus menstruasi dengan kejadian anemia pada remaja putri. Nilai OR antara siklus menstruasi pendek dengan siklus menstruasi normal pada kejadian anemia adalah 6,56 (95\% CI:2,92-14,76) artinya remaja putri dengan siklus menstruasi yang pendek 6,56 kali lebih beresiko untuk menderita anemia dibandingkan dengan remaja putri dengan siklus menstruasi yang normal. Sedangkan nilai OR antara siklus menstruasi panjang dengan siklus menstruasi yang normal pada kejadian anemia adalah 2,10 (95\% CI:0,74-5,98) artinya remaj putri dengan siklus menstruasi yang panjang 2,10 kali lebih beresiko untuk menderita anemia dibandingkan dengan remaja putri dengan siklus menstruasi yang normal.

Tabel 5 Hubungan Tingkat Konsumsi Zat Besi Dengan Kejadian Anemia Pada Remaja Putri

\begin{tabular}{|c|c|c|c|c|c|c|c|c|}
\hline \multirow{3}{*}{$\begin{array}{c}\text { Lama } \\
\text { Menstru } \\
\text { asi }\end{array}$} & \multicolumn{4}{|c|}{ Anemia } & \multirow{2}{*}{\multicolumn{2}{|c|}{ Total }} & \multirow{3}{*}{$\begin{array}{c}\text { OR } \\
(95 \% \mathrm{CI})\end{array}$} & \multirow{3}{*}{ P-Value } \\
\hline & \multicolumn{2}{|c|}{ Ya } & \multicolumn{2}{|c|}{ Tidak } & & & & \\
\hline & n & $\%$ & n & $\%$ & n & $\%$ & & \\
\hline Kurang & 63 & 61,2 & 40 & 38,8 & 103 & 100 & 21,53 & \\
\hline Cukup & 3 & 6,8 & 41 & 93,2 & 44 & 100 & $(6,25-$ & 0,000 \\
\hline Total & 66 & & 81 & & 147 & & & \\
\hline
\end{tabular}

Berdasarkan tabel 5 diperoleh hubungan antara tingkat konsumsi zat besi dengan kejadian anemia bahwa ada sebanyak $61,2 \%$ remaja putri dengan tingkat konsumsi zat besi yang kurang menderita anemia, sedangkan remaja putri dengan tingkat konsumsi zat besi yang cukup $6,8 \%$ menderita anemia. Perbedaan ini bermakna secara statistik dengan $p$-value 0,000 artinya ada hubungan yang signifikan antara tingkat konsumsi zat besi dengan kejadian anemia pada remaja putri dengan nilai OR=21,53 (95\% CI:6,25-74,19). Nilai tersebut menunjukkan bahwa remaja putri dengan tingkat konsumsi zat besi yang kuramg 21,53 kali lebih beresiko untuk menderita anemia dibandingkan dengan remaja putri dengan tingkat konsumsi zat besi yang cukup.

Berdasarkan tabel 2 dari 147 responden terdapat 66 siswi (44,9\%) yang mengalami anemia dan sebanyak 81 siswi $(55,1 \%)$ yang tidak mengalami anemia. Angka prevalensi anemia ini tergolong tinggi bila dibandingkan dengan data kejadian anemia pada remaja putri di Indonesia berdasarkan RISKESDAS tahun 2015 yaitu sebesar 21,7\%. Angka tersebut juga hampir mendekatai prevalensi kejadian anemia pada remaja putri di negara-negara berkembang, termasuk Indonesia sekitar 53,7\% dari seluruh remaja putri menurut WHO tahun 2011. Penelitian yang dilakukan Noorbaity pada tahun 2016 mengenai "Hubungan Antara Asupan Zat Besi dan Vitamin C dengan Kejadian Anemia Pada Remaja Putri di SMA Negeri 3 Palangka Raya" juga melaporkan bahwa 74\% remaja putri di SMA Negeri 3 Palangka Raya menderita anemi anemia. Dari hasil pemeriksaan juga didapatkan rata-rata kadar hemoglobin remaja putri adalah 12,83 gr/dl (Noorbaity, 2016). Kadar hemoglobin minimun adalah 8,00 gr/dl dan maksimum 
ialah 21,80 gr/dl. Batas normal dari kadar $\mathrm{Hb}$ dalam darah disebut cut off point (titik pemilah). Menurut WHO batas ambang anemia untuk wanita usia 12 tahun keatas adalah apabila konsentrasi atau kadar Hb dalam darah kurang dari 12 gr/dl.

Hasil penelitian menunjukkan bahwa dari 147 responden terdapat 86 siswi $(58,5)$ dengan lama menstruasi yang normal, dan sebanyak 61 siswi $(41,5 \%)$ dengan lama menstruasi yang tidak normal. Lamanya menstruasi normal adalah 37 hari dan rata-rata 4-6 hari. Seorang wanita yang saat menstruasi 1-2 hari diikuti dengan keluarnya darah sedikit-sedikit dan ada pula yan sampah lebih dari 7 hari oleh beberapa ahli dikatakan memiliki lama menstruasi yang tidak normal. Hasil penelitian juga menunjukkan hubungan antara lama menstrusi dengan kejadian anemia bahwa ada sebanyak $77,0 \%$ remaja putri dengan lama menstruasi yang tidak normal menderita anemia sedangkan remaja putri dengan lama menstruasi yang normal $22,1 \%$ menderita anemia. Perbedaan ini bermakna secara statistik dengan $p$-value $\mathrm{OR}=11,84$. Nilai tersebut menunjukkan bahwa remaja putri dengan lama menstruasi yang tidak normal 11,84 kali lebih beresiko untuk menderita anemia dibandingkan dengan remaja putri dengan lama menstruasi yang normal.

Hasil penelitian ini sejalan dengan penelitian yang dilakukan oleh Febrianti, dkk pada tahun 2013 mengenai "Lama Haid dan Kejadian Anemia Pada Remaja Putri di MAN 2 Bogor" yang menyatakan bahwa ditemukan hubungan yang bermakna antara lama haid dengan kejadian anemia remaja putri dengan $p$ value 0,028. Sehingga, daat disimpulkan prevalensi anemia di MAN 2 Bogor berhubungan dengan lama haid (Febrianti, 2013). Penelitian Wilyati, dkk pada tahun 2012 mengenai "Faktor Terjadinya Anemia Remaja Putri di SMA Kabupaten Kepulauan Selayar" menyatakan hal yang sama bahwa ada hubungan yang bermakna antara lama menstruasi dengan kejadian anemia ( $p$-value 0,011). Sehingga, dapat disimpulkan faktor terjadinya anemia berhubungan dengan lamanya menstruasi pada remaja putri di SMA Kabupaten Kepulauan Selayar (Wilyati, 2012). Fauziah mengemukan bahwa seorang wanita memiliki lama menstruasi yang berbeda. Lamanya menstruasi normal adalah 3-7 hari dan ratarata 4-6 hari. Lama menstruasi berpengaruh terhadap banyaknya darah yang hilang selama menstruasi. Apabila darah yang keluar saat menstruasi cukup banyak berarti jumlah zat besi yang hilang dari tubuh juga cukup besar. Lama menstruasi yang lebih dari 7 hari atau jumlah darah yang keluar saat menstruasi sangat banyak atau melebihi $80 \mathrm{cc}$ akan menyebabkan anemia Perbedaan lama menstruasi dipengaruhi oleh beberapa faktor yaitu faktor psikologis, lingkungan, usia serta ketidakseimbangan hormon. Oleh sebab itu, remaja putri dengan lama menstruasi yang tidak normal sangat mungkin terkena anemia. (Fauziah, 2012).

Hasil penelitian menunjukkan dari 147 responden 69 siswi (46,9\%) dengan siklus menstruasi yang pendek, 54 siswi $(36,7 \%)$ dengan siklus menstruasi yang normal dan 24 siswi (16,3\%) dengan siklus menstruasi yang panjang. Panjang siklus menstruasi yang dianggap sebagai siklus menstruasi normal adalah 28 hari. Panjang menstruasi bervariasi antara 21-35 hari. Hasil penelitian juga menunjukkan hubungan antara siklus menstruasi dengan kejadian anemia ada sebanyak $65,2 \%$ remaja putri dengan siklus menstruasi yang pendek menderita anemia, sedangkan remaja putri dengan siklus menstruasi yang normal 22,2\% 
menderita anemia dan sebanyak $37,5 \%$ remaja putri dengan siklus menstruasi yang panjang menderita anemia. Perbedaan ini bermakna secara statistik dengan p-value 0,000 artinya ada hubungan yang signifikan antara siklus menstruasi dengan kejadian anemia pada remaja putri. Nilai OR antara siklus menstruasi pendek dengan siklus menstruasi normal pada kejadian anemia adalah 6,56 (95\% CI:2,92-14,76) artinya remaja putri dengan siklus menstruasi yang pendek 6,56 kali lebih beresiko untuk menderita anemia dibandingkan dengan remaja putri dengan siklus menstruasi yang normal. Sedangkan nilai OR antara siklus menstruasi panjang dengan siklus menstruasi normal pada kejadian anemia adalah 2,10 artinya remaja putri dengan siklus menstruasi yang panjang 2,10 kali lebih beresiko untuk menderita anemia dibandingkan dengan remaja putri yang siklus menstruasi yang normal.

Hasil penelitian ini tidak sejalan dengan penelitian yang dilakukan oleh Yamin pada tahun 2012 mengenai "Hubungan Pengetahuan Asupan Gizi dan Faktor Lian yang Berhubungan dengan Kejadian Anemia Pada Remaja Putri di SMA Kabupaten Selayar" yang menyatakan bahwa tidak ada hubungan yang bermakna antara siklus menstruasi dan kejadian anemia pada remaja putri dengan nilai $p$-value 0,513 dan $\mathrm{OR}=1,716$ artinya remaja putri dengan siklus menstruasi tidak normal memiliki peluang 1,716 kali untuk menderita anemia dibanding dengan remaja putri yang memiliki siklus menstruasi normal (Yamin, 2012). Namun, hasil penelitian ini sejalan dengan penelitian yang dilakukan oleh Siva, dkk pada tahun 2016 yang berjudul "Prevalence of Anemia And Its Associated Risk Factors Amog Adolescent Girl of Central Kerala” yang menyatakan bahwa ada hubungan yang bermakna antara siklus menstruasi dan kejadian anemia pada remaja putri di Central Kerala, India dengan nilai $p$-value 0,004. Sehingga, dapat disimpulkan, terdapat hubungan siklus menstruasi dengan kejadian anemia di Centra Kerala, India Siklus menstruasi adalah jarak antara mulainya menstruasi yang lalu dengan menstruasi berikutnya. Panjang siklus menstruasi yang dianggap normal yaitu 28 hari. Panjang siklus menstruasi bervariasi antara dari 21-35 hari, rata-rata 28 hari. Semakin pendek siklus menstruasi maka semakin sering frekuensi wanita mengalami menstruasi, hal ini yng dapat menyebabkan perdarahan menstruasi menjadi berlebih. (Siva, 2016)

Hasil penelitian ini juga menunjukkan dari 147 responden terdapat 103 siswi $(70,1 \%)$ dengan tingkat konsumsi zat besi yang kurang dan 44 siswi $(29,9 \%)$ dengan tingkat konsumsi zat besi yang cukup. Dari hasil pemeriksaan juga didapatkan rata-rata konsumsi zat besi remaja putri adalah 21,84 per hari. Tingkat konsumsi zat besi minimum adalah 4,80 mg/hari dan maksinum adalah 48,70 $\mathrm{mg} /$ hari. Berdasarkan angka kecukupan gizi, kebutuhan zat besi pada remaja perempuan (10-19 tahun) adalah $26 \mathrm{mg} /$ hari dikarenakan perempuan memiliki siklus reproduksi yang unik.

Hasil penelitian juga menunjukkan ada hubungan antara tingkat konsumsi zat besi dengan kejadian anemia ada 61,2\% remaja putri dengan tingkat konsumsi zat besi yang kurang menderita anemia, sedangkan remaja putri dengan tingkat konsumsi zat besi yang cukup 6,8\% menderita anemia. Perbedaan ini bermakna secara statistik dengan $p$-value 0,000 , artinya ada hubungan yang signifikan antara tingkat konsumsi zat besi dengan kejadian anemia pada remaja putri dengan 
tingkat konsumsi zat besi yang kurang 21,53 kali lebih beresiko untuk mendrita anemia dibandingkan dengan remaja putri dengan tingkat konsumsi zat besi yang cukup. Hasil penelitian ini sejalan dengan penelitian yang dilakukan oleh Kirana pada tahun 2012 mengenai "Hubungan Asupan Zat Gizi dan Pola Menstruasi dengan Kejadian Anemia Pada Remaja Putri di SMA 2 Semarang" yang menyebutkan bahwa terdapat hubungan yang bermakna antara asupan zat besi dengan kejadian anemia ( $p$-value 0,024). Sehingga, dapat disimpukan ada hubungan zat gizi dan pola menstruasi dengan kejadian anemia pada remaja putri di SMA 2 Semarang (Kirana, 2012). Penelitian Handayani dkk, pada tahun 2007 mengenai "Hubungan Pengetahuan Tentang Anemia, Lama Menstruasi Pada Remaja Putri di SMK Negeri 1 Metro Lampung" juga menunjukkan bahwa terdapat hubungan asupan zat besi dengan kejadian anemia pada siswi SMK Negeri 1 Metro Lampung ( -value 0,025) (Handayani, 2007).

Zat besi dalam tubuh manusia sebagian besar terdapat pada sel darag merah yaitu sekitar $65 \%$ dalam jaringan hati, limpa dan sumsum tulang $30 \%$ dan sekitar 5\% terdapat dalam inti sel dalam plasma dan dalam otot sebagai mioglobin. Di dalam sel darah merah terdapat hemoglobin yaitu molukel protein yang mengandung zat besi dan merupakan pigmen darah berwarna merah. Zat besi merupakan komponen yang sangat penting dari hemoglobin. Komponen utama yang memegang peranan penting dalam pembentukan darah (hemopoesis) yaitu mensintesis hemoglobin. Kelebihan zat besi di simpan sebagai protein feritin, hemosiderin di dalam hati, sumsum tulang belakang dan selebihnya di dalam limpa dan otot. Apabila simpanan zat besi cukup, maka kebutuhan untuk pembentukan sel darah merah akan selalu terpenuhi. Namun, apabila jumlah simpanan zat besi berkurang dan jumlah zat besi yang diperoleh dari makanan juga rendah maka akan terjadi ketidakseimbangan zat besi di dalam tubuh, akibatnya kadar hemoglobin menurun di bawah batas normal yang disebut anemia defisiensi zat besi. (Arisman, 2010).

\section{SIMPULAN DAN SARAN}

\section{Simpulan}

Dari 147 responden remaja putri di SMA Negeri 4 Palangka Raya terdapat 66 siswi $(44,9 \%)$ yang menderita anemia. Dari hasil penelitian, terdapat ada hubungan antara lama menstruasi dengan kejadian anemia pada remaja putri di SMA Negeri 4 Palangka Raya. Hasil penelitian juga menunjukkan, tedapat hubungan antara siklus menstruasi dengan kejadian anemia pada remaja putri dan terdapat hubungan antara tingkat konsumsi zat besi dengan kejadian anemia pada remaja putri. Sehingga dapat disimpukan, ada hubungan lama menstruasi, siklus menstruasi dan tingkat konsumsi zat besi dengan kejadian anemia pada remaja putri di SMA Negeri 4 Palangka Raya. 
Saran

Bagi pihak sekolah SMA Negeri 4 Palangka Raya diharapkan dapat bekerjasama dengan instansi kesehatan seperti Puskesmas untuk mengadakan pemeriksaan $\mathrm{Hb}$ dan pemberian tablet zat besi secara rutin kepada siswa serta memberikan pendidikan tentang hal-hal yang berkaitan dengan anemia seperti cara mencegah dan makanan sumber zat besi. Bagi remaja hendaknya aktif mencari informasi yang berhubungan dengan anemia yang menambah pengetahuan khususnya tentang asupan nutrisi yang baik untuk mencegah anemia serta tanda dan gejala terjadinya anemia. Remaja diharapka dapat melakukan memeriksakan diri secara dini apabila ditemui tanda dan gejala terjadinya anemia ke petugas kesehatan agar dapat ditangani dengan tepat.

\section{DAFTAR PUSTAKA}

Arisman.2010. Gizi Dalam Daur Kehidupan Edisi 2 . Jakarta:EGC.

Badan Kependudukan Dan Keluarga Berencana Nasional .2012. Survei Demografi Dan Kesehatan Indonesia. Jakarta: Kementerian Kesehatan,

Badan Penelitian Dan Pengembangan Kesehatan Kementerian Kesehatan RI, Laporan Hasil Riset Kesehatan Dasar (Riskesda). 2013.Jakarta: Kementerian Kesehatan RI.

Departemen Gizi Dan Kesehatan Masyarakat UI 2014. Gizi Dan Kesehatan Masyarakat. Jakarta:Rajawalo Pres.

Dinas Kesehatan Kalimantan Tengah. 2016. Profil Kesehatan Provinsi Kalimantan Tengah Tahun 2015. Palangka Raya:Dinas Kesehatan Provinsi Kalimantan Tengah

Fauziah, D.2012.Hubungan Antara Pola Menstruasi Dan Konsumsi Besi Dengan Kejadian Anemia Pada Remaja Putri Di SMA Informatika Ciamis. Skripsi. Program Studi Epidemiologi Dan Penyakit Tropik Fakultas Ilmu Kesehatan Universitas Siliwangi .Tasikmalaya.

Febrianti, Utomo W B, Adriana. 2013.Lama Haid Dan Kejadian Anemia Pada Remaja Putri. E-Jurnal Kesehatan Reproduksi 4(1)

Handayani L, Yuliasih R, Jamil D. 2007. Hubungan Pengetahuan Tentang Anemia, Lama Menstruasi Pada Remaja Putri Smk Negeri 1 Metro Lampung. Jurnal Penduduk Dan Pembangunan 7(1)

Istiany A.\& Rusilanti. 2013. Gizi Terapan .Bandung: PT.Remaja Rosdakarya.

Kementerian Kesehatan R.I.2013. Peraturan Menteri Kesehatan Republik Indonesia Nomor 75 Tahun 2013 Tentang Angka Kecukupan Gizi Yang Dianjurkan Bagi Bangsa Indonesia. Jakarta: Kementrian Kesehatan RI

Kirana.2012. Hubungan Asupan Zat Gizi Dan Pola Menstruasi Dengan Kejadian , Anemia Pada Remaja Putri Di SMA 2 Semarang. Skripsi. Fakultas

Kedokteran Universitas Diponegoro .Semarang Maryana.2012.Gizi Reproduksi.Yogyakarta:Pustaka Rihama.

Masrizal.2007. Anemia Defisiensi Besi.Jurnal Kesehatan Masyarakat II Program Studi Ilmu Kesehatan Masyarakat FK Unand Padang 
Noorbaity.2016. Hubungan Antara Asupan Zat Besi Dan Vitamin C Dengan Kejadian Anemia Pada Remaja Putri Di SMA Negeri 3 Palangka Raya, Jurusan Gizi Poltekkes Kemenkes Palangka Raya.

Siva Pm,Et Al .2016. Prevalence Of Anemia And Its Associated Risk Factors Amog Adolescent Girl Of Central Kerala. Journal Of Clinical And Diagnostic Research. 10(11):LC19-LC23.

Soekriman. 2010. Ilmu Gizi Dan Aplikasinya Untuk Keluarga Dan Masyarakat. Semarang:Departemen Pendidikan Diponegoro.

Wilyati \& Riyanti. 2012. Faktor Terjadinya Anemia Remaja Putri Di SMA Kabupaten Kepulauan Selayar, Fakultas Kesehatan Masyarakat Peminatan Kebidanan Komunitas Universitas Indonesia Depok

World Health Organizatinon .2011. The Global Prevanlence Of Anemia In 2011. WHO .Geneva.

World Health Organization 2014. Iron Deficiency Anemia: Assessment, Prevetion And Control, A Guide For Programme Managers. WHO,.Geneva.

Yamin T.2012.Hubungan Pengetahuan Asupan Gizi Dan Faktor Lain Yang Berhubungan Dengan Kejadian Anemia Pada Remaja Putri Di SMA Kabupaten Selayar, Skripsi, Fakultas Kesehatan Masyarakat Peminatan Kebidanan Komunitas Universitas Indonesia,Depok. 